\title{
Commercial cuts of Pantanal caiman meat according to sex
}

\section{Vitória Regina Takeuchi Fernandes ${ }^{1}$ Maria Luiza Rodrigues de Souza ${ }^{2 *}$ Eliane Gasparino ${ }^{2}$

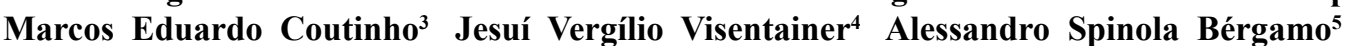 Elenice Souza dos Reis Goes ${ }^{6}$}

${ }^{1}$ Programa de Pós-graduação em Zootecnia, Universidade Estadual de Maringá (UEM), Maringá, PR, Brasil.

${ }^{2}$ Departamento de Zootecnia, Universidade Estadual de Maringá (UEM), 87020-900, Maringá, PR, Brasil. E-mail: mlrsouza@uem.br. ${ }^{*}$ Corresponding author.

${ }^{3}$ Centro de Conservação e Manejo de Répteis e Anfíbios, Instituto Brasileiro de Meio Ambiente e dos Recursos Naturais Renováveis, Lagoa Santa, MG, Brasil

${ }^{4}$ Departamento de Química, Universidade Estadual de Maringá (UEM), Maringá, PR, Brasil.

${ }_{5}^{5}$ Departamento de Biologia, Universidade do Estado de Mato Grosso (UNEMAT), Cáceres, MT, Brasil.

${ }^{6}$ Faculdade de Ciências Agrárias, Universidade Federal da Grande Dourados (UFGD), Dourados, MS, Brasil.

ABSTRACT: This study evaluated the yield, color, and chemical composition of commercial cuts (tail, sirloin cut, back fillet, and thigh) of Pantanal caiman meat in both sexes. The yield of tail was higher than other cuts, and the yield of females (17.0\%) was higher than males (15.9\%). The thigh of males had lower protein content (20.8\%) compared with other cuts. Females showed a higher lipid content in the tail (2.4\%) and thigh (0.8\%) compared with males (1.7\% and $0.4 \%$, respectively). The tail presented the greatest content of monounsaturated fatty acids (45.2\%) and higher n6/n3 ratio (4.6). Although lightness was not different among cuts or between sexes, there were differences in color. Males have more yellowish meat compared with females. Thigh and back fillet were more reddish when compared to sirloin cut and tail, regardless of sex. In conclusion, female tail meat provided greater yield and lipid content than males, and this result was statistically significant. These findings can help producers and consumers alike, better understand yield, quality, and nutritional quality of Pantanal caiman meat.

Key words: Caiman crocodilus yacare, yield, chemical composition, colorimetry.

Caracterização dos cortes comerciais da carne de jacaré-do-Pantanal em função do sexo

RESUMO: Objetivando avaliar rendimento, cor e composição química dos cortes comerciais (cauda, filé de lombo, filé de dorso e coxa) da carne do jacaré-do-Pantanal nos diferentes sexos, foram processados 20 animais, sendo estes, dez fêmeas (3677g) e dez machos (3510g). Não houve interação significativa $(P>0,05)$ entre cortes comerciais e sexo para peso dos cortes, teor de umidade e cor. $O$ rendimento da cauda foi superior aos demais cortes, sendo o rendimento das fêmeas (17.0\%) superior ao dos machos (15,9\%). A coxa dos machos apresentou menor teor de proteína (20,8\%), em relação aos demais cortes. As fêmeas apresentaram maior teor de lipídeos na cauda (2,4\%) e na coxa (0,8\%), em relação aos machos (1,7\% e 0,4\%, respectivamente). A cauda apresentou maior quantidade de ácidos graxos monoinsaturados (45,2\%) e maior razão $6 / \mathrm{n} 3(4,6)$. A luminosidade não foi diferente entre cortes e sexos. Os machos apresentaram carne com coloração mais amarelada em relação às fêmeas, e a coxa e o file de dorso tiveram cor mais avermelhada, comparadas ao filé de lombo e cauda, independente do sexo. Concluiu-se que houve influência do sexo no corte de cauda, para o teor de lipídios e rendimento, sendo que a fêmea apresentou rendimento e lipídeos maiores que o macho.

Palavras-chave: Caiman crocodilus yacare, rendimentos, composição química, colorimetria.

\section{INTRODUCTION}

Reptiles are an important source of protein for humans, especially for people seeking low-fat foods for health reasons (HOFFMAN, 2008). In Brazil, captive farming of alligators was authorized in 1990 by the Brazilian Institute of Environment and Renewable Natural Resources (IBAMA) by the passage of Ordinance 126. Successful examples have shown that sustainable farming of the Pantanal caiman (Caiman crocodilus yacare) can contributed to a healthy ecosystem (VERDADE, 2004; VICENTE NETO et al., 2010).

Consumer interest in the Pantanal caiman has typically been related to the exploitation of leather, but more recently, caiman meat is being sold in specialty restaurants and supermarkets (TABOGA et al., 2003). Fresh caiman meat is easily marketed because of its attractive appearance and pleasant taste (ROMANELLI et al., 2002). 
Bush meat consumption and demand is increasing (RODRIGUES et al., 2007). Studies evaluating the processing yields and chemical characterization of different types of cuts obtained from the Pantanal caiman have helped to provide important subsidies for industrial processing. Moreover, they have enabled consumers to better understand the nutritional value. This study analyzed four types of commercial cuts (tail, sirloin cut, back fillet, and thigh) of male and female caiman for their chemical composition, fatty acid profile, color, and yield.

\section{MATERIALS AND METHODS}

We used 20 Pantanal caimans (Caiman crocodilus yacare) with an average age of two years. Average body weight of females $(\mathrm{n}=10)$ was $3,677 \mathrm{~g}$. Average body weight of males $(n=10)$ was of $3,510 \mathrm{~g}$. IBAMA authorized the use of wild offspring from a scientific zoo located in the municipality of Cáceres MT Brazil (Cooperativa dos Criadores de Jacaré-doPantanal - Coocrijapan). Before slaughter, animals were held in tanks, fasted for 48 hours, had their mouths tied, and their sex was determined. They were washed with chlorinated water at $0.5 \mathrm{ppm}$ immediately prior to slaughter. Alligators were desensitized with an air gun (Zilca, Gil Equipment), shot in the cranial region, bled, skinned, and gutted. Carcasses were washed in chlorinated water and chilled at 2 to $4^{\circ} \mathrm{C}$. Twenty-four hours after slaughter, carcasses were deboned and cut into four types of commercial cuts: tail, sirloin cut, back fillet, and thigh. Cuts were identified, packaged in plastic bags, frozen and stored in a cold chamber at $-18 \pm 2^{\circ} \mathrm{C}$ until analysis.

Yields of commercial cuts were determined in relation to the total weight of the specimen using this formula: yield $(\%)=($ cut weight $\div$ animal weight $)$ $\times 100$. Commercial cuts were analyzed for chemical composition, fatty acids, and colorimetry. Analyses of moisture and ash were performed in triplicate (ASSOCIATION OF OFFICIAL ANALYTICAL CHEMISTS, 2005). Crude protein content was determined in triplicate using the semi-micro Kjeldahl method (SILVA \& QUEIROZ, 2002). Extraction of total lipids was performed in accordance to BLIGH \& DYER (1959).

To analyze fatty acids, total lipids were transesterified according to the ISO methodology (1978). Methyl esters of fatty acids were separated in a gas chromatograph Varian 3380 (Varian, USA) equipped with a flame ionization detector and fused silica capillary column CP-7420Select FAME (100m, $0.25 \mathrm{~mm}$, and $0.25 \mu \mathrm{m}$ film, Varian, USA). The $\mathrm{H}_{2}$ flow was $1.0 \mathrm{mLmin}^{-1}$, with $30 \mathrm{mLmin}^{-1}$ of $\mathrm{N}_{2}$ (makeup); 30 and $300 \mathrm{mLmin}^{-1}$ for $\mathrm{H}_{2 ;}$ and synthetic air for the detector flame. A volume of $0.2 \mu \mathrm{L}$ was injected using a split ratio of 1:80. Injector and detector temperatures were 220 and $240^{\circ} \mathrm{C}$, respectively. The column temperature was $165^{\circ} \mathrm{C}$ for $18 \mathrm{~min}$, raised to $235^{\circ} \mathrm{C}$ at a rate of $4^{\circ} \mathrm{Cmin}^{-1}$, and held at that temperature for $24.5 \mathrm{~min}$. Identification of the fatty acids was performed by comparing themethyl esters retention times between Sigma standards with samples and comparing the equivalent chain length values of samples methyl esters with those data reported by STRÀNSKY et al. (1997). Fatty acid profiles are presented for each of the four types of commercial cuts.

Color of the commercial cuts of the Pantanal caiman was determined using a portable colorimeter Hunter Lab miniscan EZ (Hunter Associates Laboratory, Inc., Virginia, USA) at four different reading points per sample using D65 light source, $10^{\circ}$ viewing angle, and $30 \mathrm{~mm}$ opening of the measuring cell. Lightness values were defined as follow: $L^{*}=0$ black and $L^{*}=100$ white, $a^{*}$ (red-green component) and $b^{*}$ (yellow-blue component).

The experiment was a completely randomized using a $2 \times 4$ factorial design, with two sexes (male and female) and four types of commercial cut (tail, sirloin cut, back fillet, and thigh), using 10 replications per treatment group. Two-way analysis of variance followed by Tukey's test (Pvalue 0.05) was used to investigate relationships among weight, yield, proximate composition, and color (Statistical Analysis System, SAS Inst. Inc., Cary, NC, USA).

\section{RESULTS}

No statistically significant difference in weight of the different commercial cuts (tail, sirloin cut, back fillet, and thigh) was reported based on sex $(\mathrm{P}=0.2632)$ (Table 1). Females had a higher mean weight of cuts $(296.6 \mathrm{~g})$ compared with males $(272.9 \mathrm{~g})$, which was statistically significant $(\mathrm{P}=0.0411)$. Tail weight was greater than the weight of the other types of cuts (sirloin cut, back fillet, and thigh) $(\mathrm{P}<0.0001)$. The highest yield was reported in the tail of females $(17.0 \%)$ compared with tail yield of males $(15.9 \%)$ and that of other cuts, demonstrating a statistically significant interaction $(\mathrm{P}=0.0010)$ between cuts and sex (Table 1). Separate analysis of the types of cuts indicated that back fillet provided a lower yield $(4.8 \%)$ than other types of cuts, and the tail showed the greatest yield among the types of cuts $(16.4 \%)$.

The proximate composition of the different types of cuts according to sex is showed in 
Table 1 - Weight, yield, and statistical comparison of commercial cuts of meat from Pantanal caiman (Caiman crocodilus yacare).

\begin{tabular}{|c|c|c|c|}
\hline Sex & Cuts & Weight (g) & Yield (\%) \\
\hline \multirow{4}{*}{ Male } & Tail & $559.3 \pm 54.2$ & $15.9 \pm 0.6 b$ \\
\hline & Sirloin cut & $180.9 \pm 19.2$ & $5.2 \pm 0.3 \mathrm{c}$ \\
\hline & Back fillet & $168.2 \pm 22.8$ & $4.8 \pm 0.4 \mathrm{c}$ \\
\hline & Thigh & $183.1 \pm 22.0$ & $5.2 \pm 0.6 \mathrm{c}$ \\
\hline \multirow{4}{*}{ Female } & Tail & $622.2 \pm 114.2$ & $17.0 \pm 0.6 \mathrm{a}$ \\
\hline & Sirloin cut & $197.8 \pm 40.2$ & $5.4 \pm 0.2 \mathrm{c}$ \\
\hline & Back fillet & $173.8 \pm 39.5$ & $4.7 \pm 0.5 \mathrm{~cd}$ \\
\hline & Thigh & $193.8 \pm 41.6$ & $5.3 \pm 0.3 \mathrm{c}$ \\
\hline \multirow{3}{*}{ Sex } & -------------. & ---------------------' & -------------- \\
\hline & Male & $272.9 \pm 170.3 b$ & $7.8 \pm 4.8$ \\
\hline & Female & $296.6 \pm 201.3 \mathrm{a}$ & $8.1 \pm 5.2$ \\
\hline \multirow{4}{*}{ Cuts } & Tail & $587.6 \pm 89.8 \mathrm{a}$ & $16.4 \pm 0.8$ \\
\hline & Sirloin cut & $188.5 \pm 30.8 \mathrm{~b}$ & $5.3 \pm 0.3$ \\
\hline & Back fillet & $170.7 \pm 30.7 \mathrm{~b}$ & $4.8 \pm 0.4$ \\
\hline & Thigh & $189.4 \pm 36.6 \mathrm{~b}$ & $5.3 \pm 0.4$ \\
\hline \multicolumn{4}{|c|}{ 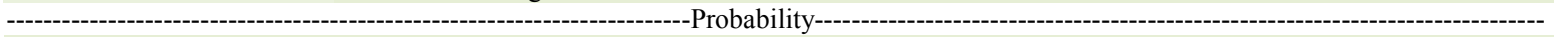 } \\
\hline & Interaction & 0.2632 & 0.0010 \\
\hline & Sex & 0.0411 & 0.0036 \\
\hline & Cuts & $<0.0001$ & $<0.0001$ \\
\hline
\end{tabular}

Data expressed in mean \pm standard deviation. Means followed by different lowercase letters are significantly different by two-way analysis of variance followed by Tukey's test $(\mathrm{P}<0.05)$.

table 2. Regardingthe moisture content, the tail had a lower moisture content $(71.5 \%)$ compared with the other types of cuts $(\mathrm{P}<0.0001)$. There was significant interaction between cuts and sex in terms of protein content $(\mathrm{P}=0.0074)$, lipid content $(\mathrm{P}<0.0001)$, and ash $(\mathrm{P}=0.0170)$. In males, crude protein content in the thigh was lower $(20.8 \%)$ compared with other cuts of males. Crude protein content values were not significantly different between males and females. Lipids in the tails of males were lower than that in females $(2.4 \%)$. Tails of females showed the greatest amount of fat $(2.4 \%)$, followed by the thigh $(0.8 \%)$,

Table 2 - Composition of commercial cuts of the meat of Pantanal caiman (Caiman crocodilus yacare) and statistical comparison of the influence of sex and type of cut.

\begin{tabular}{|c|c|c|c|c|c|}
\hline Sex & Cuts & Moisture (\%) & Protein $(\%)$ & Lipids (\%) & $\operatorname{sh}(\%)$ \\
\hline \multirow{4}{*}{ Male } & Tail & $71.2 \pm 2.4$ & $23.5 \pm 1.5 \mathrm{a}$ & $1.7 \pm 0.3 \mathrm{~b}$ & $1.4 \pm 0.1 \mathrm{a}$ \\
\hline & Sirloin cut & $75.7 \pm 0.4$ & $23.6 \pm 1.7 \mathrm{a}$ & $0.5 \pm 0.2 \mathrm{~d}$ & $1.3 \pm 0.1 \mathrm{ab}$ \\
\hline & Back fillet & $76.7 \pm 0.5$ & $23.8 \pm 1.8 \mathrm{a}$ & $0.6 \pm 0.1 \mathrm{~cd}$ & $1.3 \pm 0.1 \mathrm{ab}$ \\
\hline & Thigh & $76.8 \pm 1.1$ & $20.8 \pm 1.0 \mathrm{~b}$ & $0.4 \pm 0.1 \mathrm{~d}$ & $1.2 \pm 0.1 \mathrm{~b}$ \\
\hline \multirow{4}{*}{ Female } & Tail & $71.7 \pm 2.1$ & $22.2 \pm 1.1 \mathrm{ab}$ & $2.4 \pm 0.5 \mathrm{a}$ & $1.3 \pm 0.1 \mathrm{ab}$ \\
\hline & Sirloin cut & $75.8 \pm 0.9$ & $22.7 \pm 1.9 \mathrm{ab}$ & $0.6 \pm 0.2 \mathrm{~d}$ & $1.4 \pm 0.1 \mathrm{a}$ \\
\hline & Back fillet & $76.8 \pm 0.9$ & $22.7 \pm 2.1 \mathrm{ab}$ & $0.5 \pm 0.1 \mathrm{~d}$ & $1.3 \pm 0.1 \mathrm{ab}$ \\
\hline & Thigh & $76.6 \pm 0.8$ & $22.5 \pm 2.3 \mathrm{ab}$ & $0.8 \pm 0.1 \mathrm{c}$ & $1.3 \pm 0.1 \mathrm{ab}$ \\
\hline \multirow{3}{*}{ Sex } & & - & --Effects-----------. & ---------------- & ----------------. \\
\hline & Male & $75.1 \pm 2.7$ & $22.9 \pm 2.0$ & $0.7 \pm 0.4$ & $1.3 \pm 0.1$ \\
\hline & Female & $75.2 \pm 2.5$ & $22.5 \pm 1.9$ & $0.9 \pm 0.7$ & $1.3 \pm 0.1$ \\
\hline \multirow{4}{*}{ Cuts } & Tail & $71.5 \pm 2.2 b$ & $22.8 \pm 1.5$ & $2.1 \pm 0.4$ & $1.3 \pm 0.1$ \\
\hline & Sirloin cut & $75.7 \pm 0.7 \mathrm{a}$ & $23.1 \pm 1.9$ & $0.6 \pm 0.2$ & $1.3 \pm 0.1$ \\
\hline & Back fillet & $76.7 \pm 0.8 \mathrm{a}$ & $23.3 \pm 2.0$ & $0.6 \pm 0.1$ & $1.3 \pm 0.1$ \\
\hline & Thigh & $76.7 \pm 0.9 \mathrm{a}$ & $21.6 \pm 1.9$ & $0.6 \pm 0.2$ & $1.3 \pm 0.1$ \\
\hline \multicolumn{6}{|c|}{----------------------------. } \\
\hline \multicolumn{2}{|c|}{ Interaction } & 0.8527 & 0.0074 & $<0.0001$ & 0.0170 \\
\hline \multicolumn{2}{|c|}{ Sex } & 0.6188 & 0.2385 & $<0.0001$ & 0.8261 \\
\hline \multicolumn{2}{|c|}{ Cuts } & $<0.0001$ & 0.0062 & $<0.0001$ & 0.0067 \\
\hline
\end{tabular}

Data expressed in mean \pm standard deviation. Means followed by different lowercase letters are significantly different by two-way analysis of variance followed by Tukey's test $(\mathrm{P}<0.05)$. 
sirloin cut $(0.6 \%)$, and back fillet $(0.5 \%)$. In males, the tail also contained a greater amount of lipids (1.7\%) compared with other cuts. For ash content, the tail of males and sirloin cut of females presented higher values ( 1.4 and $1.4 \%$, respectively) compared with the ash content of males (1.2\%).

Fatty acid profiles are presented in table 3. Fatty acids identified at the highest percentage included saturated (palmitic (16:0) and stearic (18:0) acids), followed by oleic acid (18:1n-9), linoleic (18:2n-6) and timnodonic (EPA-20:5n-3). The tail showed the highest levels of saturated and monounsaturated fatty acids, as well as the highest $n 6 / n 3$ ratio, compared with other cuts. The back fillet had a higher sum of polyunsaturated fatty acids (37.1\%), followed by sirloin cut $(26.8 \%)$, thigh $(26.1 \%)$, and tail $(7.4 \%)$. The back fillet $(26.4 \%)$ and thigh $(21.3 \%)$ exhibited a higher amount of omega 3 in relation to tail and sirloin cuts.

Evaluating the color of commercial cuts of Pantanal caiman meat (Table 4), a significant interaction was $\mathrm{p}$ reported $(\mathrm{P}>0.05)$ between commercial cuts and sex for all three values measured: lightness, chroma $\mathrm{a}^{*}$ (red-green component), and $\mathrm{b}^{*}$ (yellow-blue component). Considering the commercial cuts individually, chroma a ${ }^{*}$ was highest in thigh (2.0) while the sirloin cut had the lowest chroma $\mathrm{a}^{*}(-0.8)$ $(\mathrm{P}<0.0001)$. Males had a higher mean value of chroma $\mathrm{b}^{*}$ (6.9) compared with females $(\mathrm{P}=0.0076)$.

\section{DISCUSSION}

Information on the standardization of commercial cuts, yield, meat quality, and nutritional values are important for both producers (KLUCZKOVSKI JUNIOR et al., 2015) and consumers of exotic meats. In this study, the tail provided the greatest yield from the Pantanal caiman carcass. Other studies of alligator meat have similarly reported the highest yield from the tail (ROMANELLI et al., 2002; COSSU et al., 2007; UCZKOVSKI JUNIOR et al., 2015). Alligator tail is usually processed into cross sections (10-15mm thick) and has high market value in restaurants (HOFFMAN et al., 2000). Females showed higher tail yield (17.0\%) compared with males (15.9\%), although there was no statistically significant difference for body weight between females and males. Meat processing yield may be affected by sex, weight and age of animal, types of commercial cuts, and the level of skill of the operator who makes the cuts.

Due to the higher lipid content, the tail in both sexes of Pantanal caiman showed less moisture content than the other cuts. In general, water is inversely proportional to the amount of fat in meat. Previously, ROMANELLI et al. (2002) and VICENTE NETO et al. (2007) reported similar moisture values and observed that variations in moisture content are related to the animal's weight origin, and type of cut.

Variations in crude protein content among the different commercial meat cuts of the Pantanal caiman (from $20.5 \%$ to $23.8 \%$ ) may be related to changes in the concentration of intramuscular protein, which increases during the animal's growth (ROMANELLI et al., 2002). RODRIGUES et al. (2007) examined sirloin cut, back fillet, tail fillet, and limbs in the Pantanal caiman and reported protein values of $24.2 \%, 24.4 \%, 23.6 \%$, and $24.1 \%$,

Table 3 -Major fatty acids (\%) identified in commercial cuts of the meat of Pantanal caiman (Caiman crocodilus yacare).

\begin{tabular}{|c|c|c|c|c|}
\hline \multirow[b]{3}{*}{ Palmitic acid (16:0) } & \multicolumn{4}{|c|}{ 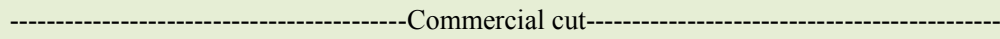 } \\
\hline & Tail & Sirloin cut & Back fillet & Thigh \\
\hline & 24.6 & 30.1 & 34.3 & 25.8 \\
\hline Stearic acid $(18: 0)$ & 20.4 & 17.4 & 15.3 & 21.6 \\
\hline Oleic acid (18:1n-9) & 42.1 & 23.5 & 13.3 & 24.0 \\
\hline Linoleic acid (18:2n-6) & 6.1 & 13.1 & 10.7 & 4.75 \\
\hline Timnodonic acid - EPA (20:5n-3) & 0.7 & 13.7 & 11.6 & 15.6 \\
\hline$\Sigma$ SFA & 47.4 & 49.8 & 49.5 & 47.3 \\
\hline$\Sigma$ MUFA & 45.2 & 23.5 & 13.3 & 26.6 \\
\hline$\Sigma$ PUFA & 7.4 & 26.8 & 37.1 & 26.1 \\
\hline PUFA/SFA & 0.2 & 0.5 & 0.8 & 0.6 \\
\hline$n-3$ & 1.3 & 13.7 & 26.4 & 21.3 \\
\hline$n-6$ & 6.1 & 13.1 & 10.7 & 4.8 \\
\hline $\mathrm{n} 6 / \mathrm{n} 3$ & 4.6 & 1.0 & 0.4 & 0.2 \\
\hline
\end{tabular}

$\Sigma \mathrm{SFA}=$ Sum of saturated fatty acids; $\Sigma$ MUFA $=$ Sum of monounsaturated fatty acids; $\Sigma$ PUFA $=$ Sum of polyunsaturated fatty acids;

PUFA/SFA = Ratio between polyunsaturated and saturated fatty acids; $n-3=$ Sum of fatty acids of the n-3 series; $n-6=$ sum of fatty acids of the $n-6$ series. 
Table 4 - Lightness (L), chroma $\mathrm{a}^{*}$ (red-green component) and $\mathrm{b}^{*}$ (yellow-blue component) of commercial meat cuts of Pantanal caiman (Caiman crocodilus yacare).

\begin{tabular}{|c|c|c|c|c|}
\hline Sex & Cortes & $\mathrm{L}$ & $a^{*}$ & $\mathrm{~b}^{*}$ \\
\hline \multirow{4}{*}{ Male } & Tail & $50.6 \pm 5.3$ & $-0.1 \pm 1.5$ & $7.8 \pm 2.4$ \\
\hline & Sirloin cut & $52.6 \pm 6.3$ & $-0.6 \pm 1.0$ & $6.5 \pm 2.3$ \\
\hline & Back fillet & $51.2 \pm 8.6$ & $1.3 \pm 2.3$ & $7.8 \pm 2.2$ \\
\hline & Thigh & $52.8 \pm 8.4$ & $2.0 \pm 1.3$ & $5.7 \pm 4.3$ \\
\hline \multirow{4}{*}{ Female } & Tail & $50.7 \pm 7.0$ & $-0.03 \pm 2.3$ & $4.8 \pm 2.7$ \\
\hline & Sirloin cut & $52.1 \pm 5.9$ & $-0.9 \pm 0.9$ & $5.3 \pm 1.7$ \\
\hline & Back fillet & $50.9 \pm 8.0$ & $0.7 \pm 1.5$ & $4.8 \pm 2.5$ \\
\hline & Thigh & $53.7 \pm 8.7$ & $2.0 \pm 2.1$ & $6.6 \pm 4.7$ \\
\hline & 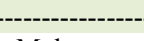 & ----------------1 & 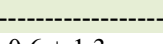 & ------------------ \\
\hline \multirow{2}{*}{ Sex } & Male & $51.8 \pm 3.4$ & $0.6 \pm 1.3$ & $6.9 \pm 1.7 \mathrm{a}$ \\
\hline & Female & $51.8 \pm 3.4$ & $0.4 \pm 1.4$ & $5.4 \pm 1.5 b$ \\
\hline \multirow{4}{*}{ Cuts } & Tail & $50.7 \pm 3.3$ & $-0,1 \pm 0.9 \mathrm{bc}$ & $6.3 \pm 2.2$ \\
\hline & Sirloin cut & $52.4 \pm 3.4$ & $-0,8 \pm 0.5 \mathrm{c}$ & $5.9 \pm 0.9$ \\
\hline & Back fillet & $51.1 \pm 3.6$ & $1.0 \pm 1.0 \mathrm{ab}$ & $6.3 \pm 1.8$ \\
\hline & Thigh & $53.2 \pm 3.2$ & $2.0 \pm 0.8 \mathrm{a}$ & $6.1 \pm 2.1$ \\
\hline \multirow{2}{*}{\multicolumn{2}{|c|}{ Sex }} & 1 & 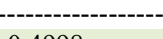 & - \\
\hline & & 0.9759 & 0.4998 & 0.0076 \\
\hline \multicolumn{2}{|c|}{ Cuts } & 0.4822 & $<0.0001$ & 0.9503 \\
\hline \multicolumn{2}{|c|}{ Interaction } & 0.9790 & 0.8528 & 0.0578 \\
\hline
\end{tabular}

Data expressed in mean \pm standard deviation. Means followed by different lowercase letters are significantly different by Tukey's test $(\mathrm{P}<0.01)$.

respectively. Other species of alligators may have lower values of crude protein, i.e., $16.9 \%$ for Caiman latirostris (COSSU et al., 2007) and 19.23\% for Melanosuchus niger (KLUCZKOVSKI JUNIOR et al., 2015). The thigh showed lower protein values $(21.6 \%)$ compared with other cuts. This may be related to the size and type of muscle fibers that make up the thigh, which differ from other parts of the carcass. Similarly, chicken thighs tend to have lower protein content compared with chest meat (ROSA et al., 2006; FARIA et al., 2009).

Ash content was also different between the type of cut and sex, and the thighs of males had lower ash content (1.2\%) compared with the tail of males (1.4\%) and sirloin cut of females (1.4\%). Despite these differences, the values are similar to those reported by others on Pantanal caiman, such as by ROMANELLI et al. (2002) and VICENTE NETO et al. (2007).

Lipid content can vary according to the season, type of feeding, and exercise intensity of the animal (KLUCZKOVSKI JUNIOR et al., 2015). In both sexes, the tail had a higher lipid content compared with other types of commercial cuts, supporting other findings that tail usually has the largest deposits of intramuscular fat (HOFFMAN \& CAWTHORN, 2014). Pantanal caimans store fat in muscle tissues of the tail, probably for use when food supplies are low (VICENTE NETO et al., 2007). Moreover, tail muscles require energy reserves to support the animal's locomotion in aquatic environments. Other studies have shown that females tend to accumulate more fat than males, showing higher lipid content in the tail $(2.4 \%)$ and thigh $(0.8 \%)$ compared with males $(1.7 \%$ for tail and $0.4 \%$ for thigh) (VICENTE NETO et al., 2007). In female mammals and reptiles, there is a predominance of somatic and visceral fat in tissues due to the sexual and reproductive function of hormonal activities. For example, flour prepared with viscera of female Pantanal caiman has $52.8 \%$ of lipids, while flour prepared with viscera of males has 23.3\% of lipids (ROMANELLI \& SCHMIDT, 2003).

Our results show that Pantanal caiman thigh, sirloin cuts, and back fillet have low total lipid content and high proportions of polyunsaturated fatty acids (Table 3), similar to those of previous research (VICENTE NETO et al., 2010). Nevertheless, in the tail, there was a greater amount of monounsaturated fatty acids $(45.2 \%)$ compared with other cuts. This result was also reported by COSSU et al. (2007) for the tail of two species of alligator (Caiman latirostris and Caiman yacare), which showed $39.2 \%$ of monounsaturated fatty acids. Tail also had a higher $\mathrm{n} 6 / \mathrm{n} 3$ ratio than the other cuts $(4.60)$, similar to the 3.16 ratio found by COSSU et al. (2007). A n6/n3 ratio close to $4: 1$ is considered to be optimal for health according to SCHAEFER (2002), demonstrating the marketing value of alligator tail. 
Color of the commercial cuts (Table 4) showed high lightness values, close to the mean values reported in white meat (RODRIGUES et al., 2007). Males have more yellowish meat compared with females (Table 4). This result may be related to the lipid content, which was lower in males than in females. Thigh and back fillet were more reddish compared with the other cuts, showing the highest values for chroma $\mathrm{a}^{*}$ (2.0 and 1.0 , respectively). This finding was similar to those reported by RODRIGUES et al. (2007) for limbs and back fillet in relation to sirloin cut and tail. Such changes may be associated with the size and type of muscle fibers (RODRIGUES et al., 2007). Values obtained for chroma a* indicated that Pantanal caiman can be classified as white meat (VICENTE NETO, 2006).

\section{CONCLUSION}

Pantanal caiman females showed a greater yield of tail and higher lipid content than males. Among the four types of commercial cuts considered, the tail has the highest yield, lowest moisture content, greatest lipid content, and greatest amount of saturated and monounsaturated fatty acids. The sirloin cut, back fillet, and thigh showed the highest total level of polyunsaturated fatty acids. Meat from males was more yellowish in color compared with that of females. For both males and females, the thigh and back fillet were more reddish in color.

\section{BIOTHICS AND BIOSSECUTITY COMMITTEE APPROVAL}

The methods were conducted in accordance with the guidelines of the Brazilian College on Animal Experimentation (COBEA) and were approved by the Comitê de Ética da Universidade Estadual de Maringá (UEM) Maringá, State of Paraná, Brasil (Protocol 149/2010-CAAE).

\section{ACKNOWLEDGEMENTS}

The authors would like to thank the Cooperativa dos Criadores de jacaré-do-Pantanal (Coocrijapan) and to Conselho Nacional de Desenvolvimento Científico e Tecnológico (CNPq) for the scholarship.

\section{REFERENCES}

ASSOCIATION OF OFFICIAL ANALYTICAL CHEMISTRIES (AOAC). Official methods of analysis of the AOAC. 18.ed. Gaithersburg, 2005. 1526p.

BLIGH, E.G.; DYER, W.J. A rapid method of total lipid extraction and purification. Canadian Journal of Biochemistry and Physiology, v.37, p.911-917, 1959. Available from: <http://www. nrcresearchpress.com/doi/pdf/10.1139/o59-099>. Accessed: oct 03, 2016. doi: 10.1139/059-099.

COSSU, M.E. et al. Carcass and meat characterization of "yacare overo" (Caiman latirostris) and "yacare negro" (Caiman yacare). Brazilian Journal of Veterinary Research and Animal Science, v.44, p.329-336, 2007. Available from: <http://www.revistas.usp.br/ bjvras/article/download/26615/28398>. Accessed: Oct 03, 2016. doi: 10.1590/S1413-95962007000500003.

FARIA, P.B. et al. Physical-chemical characteristics of meat in chickens of the Paraíso Pedrês and Label Rouge lines. Revista Brasileira de Zootecnia, v.38, p.2455-2464, 2009.Available from: <http://www.scielo.br/scielo.php?script=sci_arttext\&pi $\mathrm{d}=\mathrm{S} 1516-35982009001200023>$. Accessed: Oct 03, 2016. doi: $10.1590 / \mathrm{S} 1516-35982009001200023$.

HOFFMAN, L.C. The yield and nutritional value of meat from African Ungulates, camelidae, rodents, ratites and reptiles. Meat Science, v.80, p.94-100, 2008. Available from: <http:// www.sciencedirect.com/science/article/pii/S0309174008001642>. Accessed: Oct 03, 2016. doi: 10.1016/j.meatsci.2008.05.018.

HOFFMAN, L.C.; CAWTHORN, D.M. What is the role and contribution of meat from wildlife in providing high quality protein for consumption. Animal Frontiers, v.2, n.4, p.40-53, 2012. Available from: <https://www.animalsciencepublications. org/publications/af/articles/2/4/40>. Accessed: Oct 03, 2016. doi:10.2527/af.2012-0061.

KLUCZKOVSKI JUNIOR, A. et al. Carcass yield and proximate composition of black caiman (Melanosuchus niger) meat. International Journal of Fisheries and Aquaculture, v.7, p.4753, 2015. Available from: <http://www.academicjournals.org/journal/ IJFA/article-full-text-pdf/4AA43F752325>. Accessed: Oct 03, 2016. doi: $10.5897 /$ IJFA14.0453

RODRIGUES, E.C. et al. Quality and chemistry composition of comercial cuts of alligator swanpland meat (Cayman yacare). Ciência Agrotecnológica, v.31, p. 448-455, 2007. Available from: $\quad<$ http://www.scielo.br/scielo.php?script=sci_arttext\&pi $\mathrm{d}=\mathrm{S} 1413-70542007000200027>$. Accessed: Oct 03, 2016. doi: $10.1590 / \mathrm{S} 1413-70542007000200027$.

ROMANELLI, P.F. et al. Meat processing of Pantanal alligator (Caiman crocodilus yacare). Ciência e Tecnologia de Alimentos, v.22, p.70-75, 2002. Available from: <http://www.scielo.br/ scielo.php?script $=$ sci arttext\&pid $=\mathrm{S} 0101-20612002000100013>$. Accessed: Oct 03, 2016. doi: 10.1590/S0101-20612002000100013.

ROMANELLI, P.F.; SCHMIDT, J. Study of the utilization of the pantanal alligator's viscera for meat flour. Ciência e Tecnologia de Alimentos, v.23, p.131-139, 2003. Available from: $\quad<$ http://www.scielo.br/scielo.php?script=sci_arttext\&pi $\mathrm{d}=\mathrm{S} 0101-20612003000400025>$. Accessed: Oct 05, 2016. doi: $10.1590 / \mathrm{S} 0101-20612003000400025$.

ROSA, F.C. et al. Effect of cooking methods on carcass chemical composition and cholesterol of poultry breast and thight meat. Ciência Agrotecnologia, v.30, p.707-714, 2006. Available from: $<$ http://www.scielo.br/scielo.php?script=sci_artte xt\&pid=S1413-70542006000400017>. Accessed: Oct 05, 2016. doi:10.1590/S1413-70542006000400017.

SCHAEFER, E.J. Lipoproteins, nutrition, and heart disease. American Journal of Clinical Nutrition, v.75, p.191-212, 2002. 
Available from: <http://ajcn.nutrition.org/content/75/2/191.full. pdf + html $>$. Accessed: Oct 05, 2016.

SILVA, D.J.; QUEIROZ, A.C. Análises de alimentos. 3.ed. Viçosa, MG: UFV, 2002. 235p.

STRÀNSKY, K. et al. Standard equivalent chain length values of monoenic and polyenic (methylene interrupted) fatty acids. Journal of High Resolution Chromatography, v.20, p.143-158, 1997. Available from: <http:/onlinelibrary.wiley.com/doi/10.1002/jhrc.1240200305/ full>. Accessed: Oct 05, 2016. doi: 10.1002/jhrc.1240200305.

TABOGA, S.R. et al. Post-mortem alterations (Glycolysis) of pantanal alligator's (Caiman crocodilus yacare) muscle. Ciência e Tecnologia de Alimentos, v.23, p.23-27, 2003 Available from: <http://www.scielo.br/scielo.php?script=sci arttext $\&$ pid $=$ S0101-20612003000100006>. Accessed: Oct 05, 2016. doi: 10.1590/S0101-20612003000100006.

VERDADE, L.M. A exploração da fauna silvestre no Brasil: jacarés, sistemas e recursos humanos. Biota Neotrópica, v.4, p.1-12, 2004. Available from: <http://www.scielo.br/pdf/bn/v4n2/ a02v4n2.pdf $>$. Accessed: oct 05, 2016. doi: 10.1590/S167606032004000200002 .

VICENTE NETO, J.et al. Proximate composition and cholesterol of the alligator-swampland meat (Caiman yacare Daudin 1802) originating from captivity and wild life. Ciência e Agrotecnologia, v.30, p.701-706, 2006. Available from: <http://www.scielo.br/ scielo.php?script $=$ sci_arttext\&pid $=\mathrm{S} 1413-70542006000400016>$. Accessed: Oct 05, 2016. doi: 10.1590/S1413-70542006000400016.

VICENTE NETO, J. et al. Physichist chymistry evaluation of swampland alligator meat (Caiman yacare Daudin 1802) of different ages. Ciência e Agrotecnologia, v.31, p.1430-1434, 2007. Available from: $<$ http://www.scielo.br/scielo.php?script=sci_ar ttext\&pid $=$ S1413-70542007000500024 $>$. Accessed: Oct 05, $20 \overline{16}$. doi: 10.1590/S1413-70542007000500024.

VICENTE-NETO, J. et al. Fatty acid profiles in meat from Caiman yacare (Caiman crocodilus yacare) raised in the wild or in captivity. Meat science, v.85, p.752-758, 2010. Available from: <http:// www.sciencedirect.com/science/article/pii/S0309174010001245>. Accessed: Oct 05, 2016. doi: 10.1016/j.meatsci.2010.03.036. 